International Journal on Social Science, Economics and Art, 11 (1) (2021) 20-32

\title{
Jokowi Administration's Maritime Axis Development Policy
}

\author{
Sondang Novita Sitanggang
}

Department of Political Science, Faculty of Social and Political Sciences, Universitas Sumatera Utara, Indonesia

\begin{tabular}{|c|c|}
\hline Article Info & ABSTRACT \\
\hline & \multirow{9}{*}{$\begin{array}{l}\text { Jokowi focus their governments to make Indonesia as the pivot of } \\
\text { the maritime world greeted well considering Indonesia is a } \\
\text { country that is two-thirds of the area consists of resource-rich } \\
\text { waters and kelautan. Indonesia consists of } 92 \text { outer islands and } 31 \\
\text { of them inhabited. As stated by Sukarno, in one of his } \\
\text { speeches, Indonesia will become a strong nation if it has the } \\
\text { ability or marine waters were strong, maritime shaft also have the } \\
\text { same goal. This thesis discusses discusses the strategies and } \\
\text { policies that have been planned by the government to make } \\
\text { Indonesia as a maritime shaft. Jokowi as the pivot of the world's } \\
\text { maritime evidenced by forming ministries coordinate their work } \\
\text { and concentrated in maritime terms. Creating a strong quality of } \\
\text { human resources in the field of maritime pariisata both } \\
\text { capabilities in innovation and adaptation in the face of } \\
\text { change, work culture and concepts to be implemented. }\end{array}$} \\
\hline Received: Jan 9, 2020 & \\
\hline Revised: Sep 20, 2020 & \\
\hline Accepted: Apr 11, 2021 & \\
\hline Keywords: & \\
\hline Jokowi; & \\
\hline Jokowi Administration's; & \\
\hline Maritime Axis Development & \\
\hline Policy. & \\
\hline
\end{tabular}

This is an open access article under the CC BY-NC license.

\section{Corresponding Author:}

Sondang Novita Sitanggang,

Department of Political Science, Faculty of Social and Political Sciences,

Universitas Sumatera Utara,

Street Dr. T. Mansur No. 9, Padang Bulan Campus, Medan, 20155, North Sumatra, Indonesia

Email: sondangnov@gmail.com

\section{INTRODUCTION}

Public policy is the most important thing in running the wheels of government.1 The government is an institution that carries out political, economic and administrative authority to regulate state affairs at every level(Boris, 2015)(Michaels, 2014). In this perspective, the government includes all methods of distributing power and managing resources and public affairs. The daily reality of humans is always filled with a number of issues or problems that require immediate attention and resolution(Rahman et al., 2013)(Marshall \& Farahbakhsh, 2013). Through public policy it is hoped that all needs, interests, and desires of all people can be accommodated. Rebuilding Indonesia's maritime culture. The maritime axis policy is one of Jokowi's agendas and missions. The concept of forming Indonesia as a world maritime axis consists of five main pillars that Jokowi conveyed in his speech at the 9th East Asia Summit (EAS) on 13 November 2014 in Nay Pyi Taw, Myanmar, President Jokowi emphasized the concept of Indonesia as an Axis. World Maritime Affairs so that the development agenda will be focused on 5 (five) main pillars, namely: Safeguarding marine resources and creating seafood sovereignty by placing fishermen on the main pillar, Prioritizing infrastructure development and maritime connectivity by building sea tolls, deep seaports, logistics, shipping industry, and maritime tourism, Implementing maritime 
diplomacy, President Jokowi listed on the Nawa Cita agenda. This policy has strengthened since the enactment of Law Number 32 of 2014 concerning Maritime Affairs(Wang et al., 2014). Unfortunately, there are still several problems such as the division of central and regional authority in marine management, conflict resolution mechanisms between countries in managing marine natural resources, calculating the impact of lawlessness and marine pollution, limiting foreign participation in managing natural resources at sea, limiting individual and corporate ownership(Johannes et al., 2015). In the management of marine natural resources, as well as the involvement of indigenous peoples in the management of natural resources in the sea(Kerr et al., 2015)(Capistrano \& Charles, 2012)(BorriniFeyerabend et al., 2013). In addition, restrictions on individual and corporate ownership and management of SDALH Environmental Resources in the Marine Law are only interpreted. The ideal type of international system traditionally understood as international relations and comparative political science is that the national world "varieties" of capitalism are represented in international politics through the mediation of national governments(Thelen, 2012)(Ashman \& Fine, 2013). The maritime geography of a country opens opportunities for the country to become a maritime country that implements the continuity of foreign policy in the realization of activities within the maritime country. Indonesia is a maritime country and has been part of important maritime trade routes since prehistoric times, especially in the Strait of Malacca(Baker \& Byers, 2012)(Mukherjee \& Brownrigg, 2013). Even though Indonesia is a maritime country since prehistoric times, the utilization of the marine economic potential is still not maximized because the government is not too serious in working on the marine and fisheries sector. Widodo to develop a vision for the world's maritime axis. The vision of forming a world maritime axis is not only a domestic policy, but also a foreign oneIndonesia, not only as a shipping line, but also as a place to do business. International regimes are part of a transnational political opportunity(Manurung, 2014)(Supriyanto, 2013)(Thuy, 2014). The concept of international regime was developed in international relations theory to explain why sovereign states, in an anarchist world, often regulate relations between their countries through a system of norms, expectations and institutions, which do not always serve the direct interests of each of the states involved. and the sea resources are beradam and very rich(Zhang \& Buzan, 2012). As stated by Soekarno, in one of his speeches, Indonesia will become a strong nation if it has strong marine or marine capabilities, the maritime axis also has the same goal. This shows that the maritime axis policy is not only related to improving the welfare of the Indonesian people, but also increasing the security and comfort of other countries. Data is in the territory of Indonesia. Ocean space to become a maritime nation. Maritime economic diplomacy places the use of marine potential as part of diplomacy with other countries(Lee, 2013). This diplomatic effort can not only increase investment in Indonesia, but also strengthen cooperative relations with other countries, especially those in the Southeast Asia region(Zhongping \& Jing, 2014). If a country consists of a group of islands, its interconnected waters and other natural features can be considered as an island nation if the elements satisfy one of the two conditions. but also increase the security and convenience of other countries data is in the territory of Indonesia. Ocean space to become a maritime nation(Hamilton et al., 2014) (Branch, 2012). Maritime economic diplomacy places the use of marine potential as part of diplomacy with other countries. This diplomatic effort can not only increase investment in Indonesia, but also strengthen cooperative relations with other countries, especially those in the Southeast Asia region. If a country consists of a group of islands, its interconnected waters and other natural features can be considered as an island nation if the elements satisfy one of the two conditions. but also increase the security and convenience of other countries data is in the territory of Indonesia(Hamilton et al., 2014). Ocean space to become a maritime nation. Maritime economic diplomacy places the use of marine potential as part of diplomacy with other countries. This diplomatic effort can not only increase investment in Indonesia, but also strengthen cooperative relations with other countries, especially those in the Southeast Asia region(Connelly, 2015). If a country consists of a group of islands, its interconnected waters and other natural features can be considered as an island nation if the elements satisfy one of the two conditions. This diplomatic effort can not only increase investment in Indonesia, but also strengthen cooperative relations with other countries, especially those in the Southeast Asia region. If a country consists of a group of islands, its 
interconnected waters and other natural features can be considered as an island nation if the elements satisfy one of the two conditions (Ratcliffe, 2012). This diplomatic effort can not only increase investment in Indonesia, but also strengthen cooperative relations with other countries, especially those in the Southeast Asia region. If a country consists of a group of islands, its interconnected waters and other natural features can be considered as an island nation if the elements satisfy one of the two conditions. The idea of a maritime axis put forward by President Joko Widodo received wide attention and various responses from various groups, both at home and abroad. On the one hand, the idea is seen as a breath of fresh air amid the aridity of ideas about the future direction Indonesia wants to go. On the other hand, there are also those who are skeptical, especially because of past experiences in which the idea of Indonesian maritimeism has often been passed as mere discourse. The three elements of the maritime axis are first, maritime axis can be seen as a vision or aspiration about the Indonesia that it wants to build. In this context, the idea of a maritime axis is a big call to return to Indonesian identity or national identity as an archipelagic country, which is expected to manifest itself in the form of Indonesia as a united maritime power, prosperous, and authoritative(Nuechterlein, 2014). Second, maritime axis can also be understood as a doctrine, which provides direction regarding common goals .World Maritime, The Power Between the Two Oceans. Indian Ocean and Pacific Ocean(Nuechterlein, 2014). Third, Jokowi's maritime axis notion does not stop at the level of abstraction and conceptualization. The idea became operational when Jokowi's platform also contained a number of concrete agendas that he wanted to implement in his future administration. For example, sea highway development plan to ensure inter-island connectivity, development of the shipping and fisheries industry, port construction, improvement of sea transportation, as well as a focus on maritime security, reflects the seriousness in realizing Indonesia as a world maritime axis(Damuri et al., 2014)(Briones \& Israel, 2014). In other words, the notion of a maritime axis is also an important part of the national development agenda. However, we should not be fixated on talking about ideals, but we must immediately start working on building a strong foundation for the realization of those ideals. Third, maritime development requires large costs, sufficient technology availability, and a long time. Indonesia also needs to prepare expertise in various marine fields, ranging from those of a technical nature, technology, to experts in strategy and international maritime law. However, Indonesia has no other choice, but to immediately take and start efforts to restore its identity as an archipelagic country, which is located between two strategic oceans. In implementing the maritime axis, there are many policies that need to be revised. This regulation opens opportunities for foreign corporations to control natural resources in Indonesian seas. In terms of building a maritime axis, the main thing is to improve the welfare of fishermen and residents in coastal areas and small islands(King, 2013). ASEAN Community, connectivity at the national and regional levels is very important(Das, 2013)(Feeny \& McGillivray, 2013).

\section{RESEARCH METHOD}

The policy analysis methodology is taken and combines elements from various disciplines of science, sociology, psychology, philosophy(Dunn, 2015)(Sheets-Johnstone, 2011)(Creswell, 2011). Policy analysis is partly descriptive in nature, drawn from the discipline. Traditional disciplines (eg political science) which seek knowledge of the causes and effects of public policies. Choosing and determining the priority of one value is not a purely technical determination, but also moral reasoning. In this study the authors used a descriptive qualitative research type(Venable et al., 2012). This research wants to describe and describe the object observed based on the facts in the field after doing the research. In qualitative research, flexibility develops because it is constantly in process. In collecting the required data and information, the authors perform the following data collection techniques. Primary data as well as secondary data: searching for data and information through books, interners, journals and others related to this research. This method is often known in other words or often referred to as a research library. Usually, the data or information received by the author is incomplete and is still in a rough, random form. It needs to be rearranged, edited, corrected and then retyped. In this study the authors used descriptive qualitative research. This research wants to describe and describe the object that is 
observed based on the facts in the field after doing the research. In writing research reports, qualitative researchers play words to convey meaning.

\section{RESULTS AND DISCUSSIONS \\ 3.1. Welcoming the World Maritime Axis \\ a. Post Election}

Political awareness generally comes from the leader. Political awareness will grow when the leader has "ocean leadership" or strong maritime leadership, namely leadership that is able to produce strategic decisions for maritime advancement(Darch et al., 2015). This leadership appeared when Gusdur became President R I. He had political awareness which was manifested by the move to form the Department of Marine Exploration and Fisheries which has now changed to the Ministry of Marine Affairs and Fisheries. Gusdur is an important asset with the hope that it can further strengthen along with changes in the political regime. The 2014 election is expected to produce a strong "Ocean Leadership". The presidential election can elect a leader who has Christianity, such as GusDur, who has the courage to make decisions that have a systematic impact.

\section{b. Jokowi's promise}

During the Presidential Election campaign, Jokowi's promises were interesting to observe, these promises included increasing fisheries production by twofold, building 100 fishing centers, and developing methods of fish farming properly. There are about 7 other promises related to fisheries development where the execution framework for these promises is as follows: First, double fish production. If in 2014 the production was 1 million tons, it is estimated that in 2019 it will be around 3840 million tons. With such a large fishery production, the focus is on cultivated fish. In 2019, cultivated fish production will be boosted up to 31-33 million tons. Second, build 100 fishing centers and cultivate fish. Another popular language is Minapolitan, this is where an integrated upstream and downstream approach is needed. What does it mean that production is abundant without market access and without added value? There are three important components in the development of this center, namely: the household component, business, and infrastructure. The household component is genetic because all non-fishery numeric houses also need it, namely the Smart Indonesia card, health card, Raskin and others. Business components include guaranteed fuel supply, cheap creditors, information education for motivation, and management of production areas. In the short term what is needed is a guarantee of fuel supply, but if the framework for compensation and other forms of subsidy is clear, then the increase in fuel prices will not be a problem. In addition, management of fishery areas is generally integrated with port authorities, but for cultivation it is necessary to think further about management of areas such as Kampung Vaname, catfish village and catfish center. The components of infrastructure, including market access, transportation, water, electricity and an information system, which include these facilities and infrastructure, are important to consider small-scale air transportation to transport live fish from remote areas. Thus, building a fishing center is not only increasing production but must be intact with the aspects of facilities and infrastructure or infrastructure. The two promises seem light but carry no small link back. The conditions above need to be fulfilled so that Jokowi's promises can be realized. It is important to consider small-scale air transportation to transport live fish from remote areas. Thus, building a fishing center is not only increasing production but must be intact with the aspects of facilities and infrastructure or infrastructure. The two promises seem light but carry no small link back. The conditions above need to be fulfilled so that Jokowi's promises can be realized. It is important to consider small-scale air transportation to transport live fish from remote areas. Thus, building a fishing center is not only increasing production but must be intact with the aspects of facilities and infrastructure or infrastructure. The two promises seem light but carry no small link back. The conditions above need to be fulfilled so that Jokowi's promises can be realized.

\subsection{Strategy to Realize Maritime Axis}

The main objective of the maritime axis is to increase the sovereignty and dignity of the state or the wealth of the sea and the resources therein, as well as to strengthen the unity between the archipelago archipelago / Maritime development in fact must be able to realize equitable development between 
islands, including islands in the border region in order to reduce or even eliminate development disparities that are striking between islands. Maritime issues have an internal dimension; and external(Le Mière, 2014). The internal dimension concerns the management of territorial sea waters and activities therein for domestic interests. Meanwhile, the external dimension concerns the judicial management of the country's maritime territory which is related to cooperation and even conflicts with other countries.

\section{a. Connectivity Strengthening}

National connectivity is the integration of four elements of national policies which consist of the national logistics system, the national transportation system, area Development, information and communication technology (Banomyong et al., 2015)(Guerrero-Ibanez et al., 2015). This effort was made so that national connectivity could be realized effectively. Rfrdien and integrated. As is well known, Indonesia's connectivity is part of global connectivity, the realization of strengthening national connectivity needs to consider the connection between Indonesia and regional and world economic centers in order to increase national competitiveness. National connectivity concerns the capacity and capability of a nation in managing mobility which includes 5 , Informai concerning information mobility for the benefit of regional development which is currently closely related to mastery of information and communication technology. Strengthening connectivity can be done by maximizing the use of the SloC and ALKL. Indonesia can achieve many of the benefits and modalities of this maitim to accelerate growth in various regions of Indonesia, build maritime competitiveness, as well as increasing the resilience and sovereignty of the national economy. To benefit from the national strategic position, efforts to accelerate and expand Indonesia's economic development need to take advantage of the presence of the SloC and ALKI as sea routes for international shipping.

Here it is necessary to improve port infrastructure in terms of improving the quality of transportation routes between ports or routes to ports. In an effort to increase national development in the maritime sector, the logistics sector has a very important role. Logical work improvements are useful in lowering the cost of transporting goods and increasing competitiveness. The fundamental problem with the Indonesian marine transportation logistics system is that there are insufficient facilities and infrastructure compared to the demand for transportation services(Laxe et al., 2012). The provision of transportation ownership has so far been donated by the government and BUMN.

Responding to this problem, IPC continues to encourage the acceleration of infrastructure development in order to create an integrated national logistics system to support the growth of domestic and regional trade. Ports are known to support the distribution of large quantities of goods at a more efficient cost. If the market potential in Indonesia is very high with the largest population in Southeast Asia, the logistics potential and opportunities in Asia are enormous. The purpose of transportation development, especially sea transportation between islands between Indonesia, is to realize sea transportation as the lifeblood of the economy, social, and politics and to strengthen unity and integrity, as well as providing employment and earning the country's foreign exchange. Based on existing data, about $80 \%$ of the process of moving varang and inter-island services uses sea transportation services. For this reason, it is necessary to prepare transportation infrastructure immediately so that the economic potential trade in the archipelago can be optimally utilized. In order to make this happen, a breakthrough is needed to build transportation infrastructure. One of them is by mutually beneficial cooperation between the government and the private sector. This was done in an effort to overcome the problem of lack of budget for infrastructure development. Infrastructure development steps need support from all stakeholders, starting from the central government, regional government, private, and society.

\section{b. Develop Local and Coastal Economy}

In a regional economic perspective, The coastal area has important pillars to become a force in developing the region, these strengths are: first, natural resources advantages. In fact, in the coastal area there are concentrations of regional superiority that are not owned by other regions, namely: the superiority of natural resources, for example mangroves, Coral reefs,seagrass beds; characteristic 
cultural characteristics with egalitarian characteristics, inwork looking,and dynamins; there is a connection between the community and the coastal area. Second, economc of concentration, In this case, the special scale of business activities based on economies of scale generally occurs in types of industrial grouping, for example the fish canning industry. This grouping factor occurs because production costs are determined for labor costs and raw material transaction costs, and a leader.

Coastal and marine development must pay attention to the problems of poverty and the welfare of fishermen. Fisheries in Indonesia involve many stakeholders ythe largest number are small fishermen. Local governments can manage coastal and marine resources more rationally considering the availability of resources and the degradation of these resources will determine the level of prosperity of the community in the area concerned. Besides that, it must also be highly committed and consistent in enforcing the applicable legal regulations in order to avoid social and economic conflicts.

\section{c. Blue Economy}

Awjlan blue economy concept with green economy concept that is environmentally friendly and focused on developing countries with territorial waters (sea). In this case, the blue economy is aimed at overcoming hunger, reducing poverty, creating sustainable marine life, reducing the risk of disasters in coastal areas and mitigating and adapting to climate change. The implementation of the blue economy globally is considered crucial considering that $72 \%$ of the earth's total surface is oceans.

The blue economy is closely related to water and marine-based sectors such as the fisheries, transportation and tourism sectors. The survival of marine life as food and livelihoods for people around the sea is the focus of the blue economy in order to reduce poverty and hunger. The blue economy approach focuses on creative and innovative investment which in turn can improve the welfare of the community by paying attention to environmental sustainability. This blue economy concept was developed to answer the challenge that the world economic system tends to be exploitative and disruptive to the environment. This environmental damage is not only caused by industrial waste, however, damage to nature and the environment is also caused by exploitation of natural resources that exceeds capacity.

In the end, the blue economy will guarantee that a development that is carried out will not only carry out economic growth but also ensure ecological and social sustainability. A blue economy can be understood as an economic model to encourage the implementation of development along with a framework such as the way ecosystems work. The marine economy with a blue economy model is built on four pillars, namely: Integration of land and sea development, Clean construction, inclusive, and sustainable, Increasing the added power and competitiveness of products through innovation, and Increase in equitable community income, equally, and deserve. To be able to support the implementation of a blue economy that is oriented towards reativity and innovation, the government needs to increase the knowledge and skills of coastal communities so that they are able to experiment. By increasing innovation and socialization of agricultural and marine science and technology, it is hoped that it can increase the cultivation of marine products. Infrastructure that promotes maritime efficiency, like a port, The management and marketing aspects of the marketing results also receive better attention. Thus, the blue economy is expected to support sustainable development.

\section{d. Marine Economic Development}

Indonesia has the potential for large and diverse marine development. Capture fisheries, Aquaculture, Fishery product processing industry, marine biotechnology industry, Mining and energy, Maritime tourism, Sea transportation, Trade services, Maritime industry, Small islands, Unconventional resources, marine buildings, Valuables and cultural heritage, Conservation environmental services and biodiversity. Indonesia has abundant marine alternative energy resources. If managed properly, these various sectors have enormous potential to be developed to produce superior products. meanwhile, production demand is expected to continue to increase in line with the increase in world population, so it is believed that the marine economy can become a competitive advantage and solve the problems of the nation.

1) Diversification of Mining Resources and Utilization of Marine Energy 
Mining is the main sector in marine development which has a large enough potential. This potential still requires follow-up through exploration in order to obtain new reserves because the resource will someday run out. However, the development of mining in the era of regional autonomy must provide exploitation for local communities. Increased exploitation and exploitation of mining and energy resources must consider ecosystems with other resources. As the largest archipelago with extraordinary natural characteristics, Indonesia has abundant marine alternative energy resources, arguably the best and largest in the world. In developed countries, competing to utilize marine energy as an alternative energy resource. Some alternative energy sources: tidal energy, ocean tide energy, ocean wave energy, and marine algae energy

2) Maritime Tourism Development

The marine tourism sector is the most efficient sector in the marine sector, so that the development of marine tourism needs to get priority. In essence, the development of marine tourism is an effort to develop and utilize marine tourism objects and attractions in the coastal areas and oceans of Indonesia. To improve the marine tourism sector, the five main components of the marine tourism procurement side, namely: tourism object, transportation, cruise, promotion and information. The first strategy, mapping the potential of marine tourism, namely value, characteristics, supporting infrastructure and the ability to support the economy. Second, compiling investment and development plans based on various information that we have obtained from the above mapping. Third, creating quality human resources that are strong in the field of marine tourism, both the ability to innovate and adapt in the face of various changes, work culture and concepts to be implemented. Fourth, adopt a good marketing strategy. Like doing promotions in various media. Fifth, maximizing the marine tourism sector. These strategies will be meaningful if the government, investors, banks and communities come together to develop marine tourism for the prosperity of society and the country.

3) Fisheries Development

The fisheries sector also has the potential to be the main driver of the economy Indonesia. To utilize the potential of fishery resources and make this sector the prime mover of national economic development, accelerated efforts and breakthroughs in maritime and marine development are needed, which are supported by political and economic policies. Fisheries development aims to increase fishermen's income by increasing productivity, expand job opportunities and business opportunities. Indonesian fisheries development trilogy, namely: control capture fisheries, develop aquaculture, improve quality and added power. The process of exploiting fishery resources must have a common vision of fisheries development, which is a fishery development that can optimally utilize fish resources and their ecosystems for the welfare and progress of the Indonesian nation. Where the fisheries sector must be able to create national economic growth, must be able to provide significant benefits, and fisheries development must be eco-friendly, which means that it must pay attention to environmental sustainability and carrying capacity. First, the fisheries sector must be able to create national economic growth through increasing foreign exchange, increase in the average income of actors and able to increase the contribution to GDP. Second, the fishery sector must be able to provide significant benefits to actors by raising the level of welfare of fishery actors.

4) Naval Fleet Development

The national development perspective is the insight into the development of the archipelago as a regional, political and economic unit. So that to develop an archipelago whose territory is $75 \%$ sea, strong sea transportation is needed to facilitate the flow of goods and services. First, from the software aspect. This is done by developing supportive policies, including ratifying international maritime laws that encourage the development of national shipping. Second, from the hardware aspect. For this reason, a policy is needed to increase the number of national fleets by formulating policies on the development of the national shipping industry. With the 
existence of marine policies of this kind, it is hoped that the marine transportation sector can become a master in their own country.

5) Maritime Industry Development

The maritime industry is one of the industrial strategies chosen as part of the various spearheads of technology-based industries and globalization strategies to accelerate domestic development and advance Indonesia's role in international competition. In general, the national maritime industry is a little behind from various countries. Even though the maritime industry is included in it, shipyard repair services industry, ship machinery industry and its equipment. The ability of the Indonesian people in the maritime industry is very limited due to the high investment value. The strategy for economic development in the maritime industry sector is directed at building a maritime industry that is clean of waste, efficient, strong and independent and able to provide high added economic value in order to accelerate the growth of the national marine economy. The maritime industry has a broad scope and is integral to other industries on the mainland. With the development of the maritime industry it is hoped that it will become a process of socio-economic transformation in coastal communities so that the positioning of the maritime industry as part of the mainstream of economic development is crucial for the growth of the national maritime sector.

6) Biotech, Pharmaceutical, and Genetic Data Sources Industry

Indonesia, which most of its territory consists of waters, stores a very large marine biodiversity in both number and type. Marine and fisheries biotechnology is a technique that applies basic sciences and engineering sciences to process materials using organisms that live in the sea through controlled processes so that they become useful products aimed at utilizing cells or enzymes contained in marine organisms for various applications or needs. human including the restoration of the environment that has been damaged. One thing that has been forgotten about the development of marine biotechnology is that this resource can be developed as a source of food and medicine.

7) Marine Services Development

Marine services which consist of all types of activities that support and facilitate activities in the marine sector such as port services, safety shipping, marine resource development, as well as education, training, and research. Market opportunities for potential marine services must be prepared from now on because their characteristics require excellence of human resources. Thus the role of the marine services sector becomes significant in order to support marine development in a comprehensive and integrated manner. The implication is that this sector is expected to be able to improve the quality of marine management resources and absorb more skilled workers. The development of the marine sector as the spearhead of national economic development.

\subsection{Policy}

Awareness of the shift in the development paradigm from a continental orientation to a sea orientation should be realized in the form of policy support that is comprehensive and concrete, systematic, not partial, let alone sporadic. Maritime or maritime-based economies are no longer used as a peripheral sector to facilitate the mainstream sector in development policies. Martim economic development makes the wealth of maritime potential as the basis for providing quality infrastructure, especially in the maritime sector so that a good maritime climate and investment will develop.

a. Regulation, Law Enforcement and Institutions

The development of marine development policies is also closely related to regulations and institutions. Planning process, formulation, as well as the establishment of policies or laws and regulations relating to the management of coastal and marine resources to take the following approaches: First, regulations to be applied based on the needs and social characteristics of the community. This is motivated by the idea that the introduction of a policy to the community is often only based on a recommendation from an official or agency at the central level that has little or no improvement in local institutions. Therefore, in planning the formulation of legal development, it is necessary to avoid past patterns, namely that the 
recommendations that are used as the basis for community regulation are from an institution that is completely far from community interaction which because of the fact that regulations are often issued fail to be established in the community. Second, preaturan-made regulations often use policy strategies that are homogenized but heterogeneous in nature, meaning that a regulation can no longer be applied to all groups of people in an area. So the formulation of a regulation for coastal communities must pay attention to the dimensions of the needs and characteristics of the social needs of the target community. Basic legal development plan, namely based on the needs of communities in coastal areas and based on local initiatives, which means that existing regulations are more global in perspective and concern basic policies. Second, Marine policy is an archipelagic state policy so that spatial variables must be complete, not only marine monodimensional. Third, all obligations stated in UNCLOS must be carried out, because it is important for the effectiveness of our sovereignty. Fourth, build a vision as well as maritime power to answer the geopoitic demands of the nation.

This is consistent with spatial perceptions and perceptions of competitive advantage based on natural resources, culture, Science, and geography. The formation of the Department of Marine Affairs and Fisheries by the government is a step forward to continue the maritime vision, it can be said that the policy becomes a political economy decision and a fundamental change process at the macroeconomic policy level. Until the end of 2015, there were a number of breakthroughs that stunned the public in the form of Permen No. 56 and 57 / Permen-KP / 2015 concerning a moratorium on ex-vessels without permission. trawling as experienced by fishermen at the port of Deli Belawan. Until the end of 2015, there were a number of breakthroughs that stunned the public in the form of Permen No. 56 and 57 / Permen-KP / 2015 concerning a moratorium on ex-ships without permission. In order to maintain Indonesia's existence as an archipelagic country that is intact and comprehensive, the integration of Indonesian waters as an integral part and one territorial unit with the land and air space above must be maintained, maintained and protected.

Concretely, to be able to protect Indonesia's interests and create security conditions in Indonesian waters, it is necessary to enforce law at sea, including law enforcement in Indonesian waters and additional zones. In terms of regulations protecting national interests at sea, stabilization of the legal basis regulating the territorial waters has been established. Indonesia, given the swift development and changes of the strategic environment at the global, regional and national levels which affect the joints of the life of the nation and state. In the implementation of law enforcement at sea, there are differentiated between: The law enforcement function is related to certain criminal acts at sea and the law enforcement function is related to general crimes that occur at aut. The implementation of law enforcement at sea relating to certain crimes listed in the legislation constitutes a special provision of criminal procedural law. Based on the above understanding, then the implementation of law enforcement at sea is activities at sea which include supervision, stopping the ship including tackling, and examination, and investigations if there is a criminal act. Meanwhile, further settlement will be carried out on land. According to the Permanent Procedure for Handling (Protap) aut crime by the Indonesian Navy, which includes the types of marine crimes are: Meanwhile, further settlement is carried out on land. (1). Robbery / piracy at sea (2). Fisheries crime (3). The criminal act of valuable objects buried by a ship sinking on the seabed (4). Environmental crime (5). The crime of shipping (6). Customs crime (7). The criminal act of mining sand at sea (8). Criminal act of territorial violation (9). Criminal acts in Indonesia's EEZ Law enforcement at sea is very necessary for safeguarding at sea, given the various forms of threat of disturbance to marine use or exploitation activities, among others: (a). Threats of violence, that is, threats using organized force of arms that have the ability to disrupt and endanger state personnel. (b). The threat of naigation, namely the threat posed by the geographical conditions and the lack of adequate navigation aids (c). The threat is sea resources, namely in the form of pollution and destruction of marine ecosystems, as well as conflict over natural resource management which tends to be politicized, (d). Threat of violating the law, namely non-compliance with national and international laws that apply in waters. Considering the possibility of overlapping authority possessed by the related agencies, so to ensure that law enforcement in the Indonesian waters can be 
carried out effectively and efficiently, a very important factor is coordination, especially in vulnerable situations., without losing the functional authority of each agency. To ensure the smooth and orderly exercise of authority and coordination in law enforcement in Indonesian waters, then the facilities and infrastructure are the relevant law enforcers who have capabilities in all related aspects, including the ability to understand the prevailing laws and regulations. Furthermore, the strategic plan for institutional development should be based on development objectives, namely increasing the socioeconomic role of coastal communities in the development process as for the purpose of strengthening marine institutions, including: increasing the effectiveness of operational implementation and coordinating cross-sectoral policies, programs and activities in the marine sector, strengthening marine institutions to develop development systems. based on the concept of an archipelago nation and strengthening Indonesia as a maritime country.

\section{b. Budget Politics}

Budget policy also greatly influences the realization of the maritime axis. The budget for the maritime sector includes maritime-based provinces and small islands such as thermal-jinaization so that it implies a lack of development facilities and infrastructure. Pan-oriented budget politics can of course refer to the development of marine economic sectors and the economic development of local communities and coastal areas.

\section{c. Infrastructure}

Generally, infrastructure related to various capital goods, like the road, seaports, and air, energy, irrigation, financial system communication network, special economic areas and others. The availability of adequate infrastructure is the key to success in accelerating the development of a country, both in terms of economic and social development. Failure to properly invest in infrastructure indicates failure to maintain and improve the social and economic well-being of a new country in a sustainable manner. The benefits of infrastructure to support economic and social development include the following: increasing the productivity of public labor, thereby reducing production costs, increasing operating profits, increasing the amount of production, increasing employment, and increasing community income; This has significant implications for achieving the targets of sustainable development, accelerating equitable development through infrastructure development tailored to the needs of the region; to encourage new investment, increase connectivity between residents and open isolation to underdeveloped communitiesfacilitate the flow of ideas to provide added power in economic and social activities and encourage allocation of resources because infrastructure facilitates access for labor and raw materials and provides opportunities for alternative activities. Based on the above matters, hence serious efforts are needed to increase the availability of adequate infrastructure, both in terms of quantitative, quality, and ease of access.

Based on The Global Competitiveness Report 2013/2014 prepared by the World Economy Forum, Indonesia's competitiveness is ranked 38th in the world. Meanwhile, Indonesia's infrastructure quality ranks 61 out of the 148 countries surveyed in the world. Or is in the\% rank among ASEAN countries. The data above then underwent a change, namely an increase in four digits with the progress of the 2014/2015 WEF data. Indonesia's global competitiveness in the 2014/2015 period increased by four ranks from 38 to 34. Meanwhile, in terms of infrastructure and connectivity, Indonesia's ranking increased from 61 to 56,2011 . In the ASEAN region, Indonesia has a number of sea ports of 28 units of which 2.187 units are domestic ports and 151 units are international ports. 114 With this description of maritime development, it is clear that the strength of the commercial and fishery shipping fleets is the tip of the waves and a measure of the success of economic development or the national maritime industry. The cobate principle which has been expressly set to be determined is a fundamental policy for the development of the maritime industry. In essence, to develop the economy or maritime industry, the government needs to immediately apply credit and tax intensive for procurement, operation and maintenance of ships as applied by the governments of other countries.

d. Human Resource Development (HR)

In the midst of competitive challenges and global competition, the development of quality human resources is a strategic asset. Human resource development in the marine and fisheries sector has a 
strategic role in managing and utilizing marine and fisheries resources. With the ability of human resources, it will be the driving force for the sustainable development of the marine sector. Human resources are the most important part of running the nation's economy. In the era of globalization, competition in various lines is increasingly competitive. Professional support is needed, as well as for the sake of developments in the maritime sector, professionalism will provide its own advantages for individuals who work in that sector and in any sector. Laode Kamalauddin, mention, HR working in the maritime sector can be grouped into seven categories, namely: as a sailor on domestic and foreign commercial vessels as a catcher of fish on domestic and international vessels as a sailor on public and fisherman shipping, workforce on offshore marine exploration employees working in ecotourism and employees in the port sector It is not impossible for Indonesia to be developed into a large maritime nation if it has quality human resources. Even, 2014 international statistical data, placing Indonesia in third place out of the top ten countries providing world seafarers, It is encouraged by the assumption of the labor market in the maritime sector which continues to grow considering that the maritime sector has very strong multi-sectoral linkages, then the potential for human resource development in the maritime sector is expected to run more optimally. The government can strengthen human resources through maritime vocational education and maritime universities. In addition, the government is also developing job training centers in the maritime sector. In addition, training was held for crew members of Indonesian fishing boats with a size of more than 30 GT who were operating at ZE.

e. Utilization of Marine Technology

The development of technology is not separated from human life, natural resources can be used in parallel with technological developments to enhance added value that runs continuously. Technology is not just natural, every time there are new innovations made by creativity, human initiative and work. This was developed by Peter Drucker, where technology as a benchmark for the progress of development of a nation, the acquisition of which is not as easy as imagined because Indonesia has not yet been involved in technology and technology transfer, especially in the field of marine natural research. In order to overcome technological problems that are really needed in the context of Indonesia's economic growth, a breakthrough can be made with technological planning, so as to determine the direction and target of the technology, among others by: Planning for domestic technology through research and experts, Entering foreign technology through technology transfer in accordance with development needs; and Expertise and assistance which can be in the form of: pre-investment, machine specifications, installation and operation of machines and management. Domestic technology planning through research and experts Work behind technology by changing existing gaps by studying the needs of science and technology on an ongoing basis. Working on individual foreign experts, Organizing supplies and machines and other verat tools that are arranged in separate contacts. License agreements with technology owners can facilitate technology and rights for people implementing technology with a license The ability to control marine technology which is the national capital to be able to manage the marine resources and territories of the archipelago needs to be further improved, especially through increasing the intensity of research and development activities in strategic sectors. Management of marine resources needs to focus on activities to utilize the wealth of owned resources that are balanced by maintaining a balance between economic interests and ecological balance. In order to realize maritime sector, there are several things that are being done by the government. First: establishing an ocean policy which is followed up with the formulation of a Maritime Grand Strategy to encourage the use of marine resources to become one of the main drivers of economic development through the use of technology and industrial research collaboration. Second; utilization of national marine resources that can be defined as mainstream in national economic development to increase national economic resilience in the marine sector. Third: formulate a mapping of marine resources that can be developed through the efforts of the people's economy, which can be developed through industrialization on a large scale of business. Fourth: accelerate and develop marine and fisheries industrialization through 
the concept of blue economy development as well as formulate investment regulations that are conducive to exploitation and exploration of marine resources.

\section{CONCLUSION}

Government policy is an institution that exercises political, economic and administrative authority to regulate state affairs at every level. Governance is a complex mechanism, involving processes and institutions as a vehicle for citizens and community groups to articulate interests, exercise rights and obligations, and mediate public differences which are the most important things in running government. Indonesia's policy is a maritime country and has been part of important maritime trade routes since prehistoric times, especially in the Strait of Malacca. Even though Indonesia is a maritime country since prehistoric times, the utilization of the marine economic potential is still not maximized because the government is not too serious in working on the marine and fisheries sector. The maritime axis policy is one of Jokowi's agendas and missions. Maritime axis policy is not only related to improving the welfare of the Indonesian people, but also increasing the security and comfort of other countries. Data is in the territory of Indonesia. The formation of a working cabinet is expected to support and assist the realization of this maritime axis with a mutually sustainable work agenda and with the establishment of a coordinating ministry for maritime affairs. The Coordinating Ministry is present as an accelerator of existing economic development as well as a meeting point for relations between sectors and a monitoring agency to achieve the targets that have been decided by the President. So far, the process of realizing the maritime axis of the Jokowi-JK administration has been going well, with a strategy of strengthening connectivity, developing local and coastal economies, blue economy, marine economic development. Where marine economic development focuses on certified mining resources, marine tourism development, fisheries development that has made several breakthroughs: the first breakthrough Permen No. 56 and 57 / Permen-KP / 2015 concerning the moratorium on ex foreign ships: the second breakthrough Permen No.1 / Permen- KP / 2015 regarding the regulation of catching three species of fisheries: The third move of Permen No.2 / Permen-KP / 2015 concerning the prohibition of the use of trawl fishing gear, development of sea transportation fleets, development of maritime industry, and development of marine services And with the implementation of policies in the form of increasing regulations, enforcing maritime laws and institutions, focusing the APBN on budget politics, improving the quality of marine infrastructure,

\section{REFERENCES}

Ashman, S., \& Fine, B. (2013). Neo-liberalism, varieties of capitalism, and the shifting contours of South Africa's financial system. Transformation: Critical Perspectives on Southern Africa, 81(1), 144-178.

Baker, J. S., \& Byers, M. (2012). Crossed lines: The curious case of the Beaufort Sea maritime boundary dispute. Ocean Development \& International Law, 43(1), 70-95.

Banomyong, R., Thai, V. V, \& Yuen, K. F. (2015). Assessing the national logistics system of Vietnam. The Asian Journal of Shipping and Logistics, 31(1), 21-58.

Boris, O. H. (2015). Challenges confronting local government administration in efficient and effective social service delivery: The Nigerian Experience. International Journal of Public Administration and Management Research, 2(5), $12-22$.

Borrini-Feyerabend, G., Farvar, M. T., Renard, Y., Pimbert, M. P., \& Kothari, A. (2013). Sharing power: A global guide to collaborative management of natural resources. Routledge.

Branch, A. (2012). Elements of port operation and management. Springer Science \& Business Media.

Briones, R. M., \& Israel, D. C. (2014). Enhancing supply chain connectivity and competitiveness of ASEAN agricultural products: Identifying chokepoints and opportunities for improvements. Philippine Institute for Development Studies.

Capistrano, R. C. G., \& Charles, A. T. (2012). Indigenous rights and coastal fisheries: a framework of livelihoods, rights and equity. Ocean \& Coastal Management, 69, 200-209.

Connelly, A. L. (2015). Sovereignty and the sea: President Joko Widodo's foreign policy challenges. Contemporary Southeast Asia, 1-28.

Creswell, J. W. (2011). Controversies in mixed methods research. The Sage Handbook of Qualitative Research, 4, 269284.

Damuri, Y. R., Atje, R., Alexandra, L. A., \& Soedjito, A. (2014). Maritime Silk Road and Indonesia's Perspective of Maritime State. Centre for Strategic and International Studies.

Darch, P. T., Borgman, C. L., Traweek, S., Cummings, R. L., Wallis, J. C., \& Sands, A. E. (2015). What lies beneath?: 
Knowledge infrastructures in the subseafloor biosphere and beyond. International Journal on Digital Libraries, 16(1), 61-77.

Das, S. B. (2013). Enhancing ASEAN's Connectivity. Institute of Southeast Asian Studies.

Dunn, W. N. (2015). Public policy analysis. Routledge.

Feeny, S., \& McGillivray, M. (2013). The role of ASEAN connectivity in reducing the development gap. Routledge.

Guerrero-Ibanez, J. A., Zeadally, S., \& Contreras-Castillo, J. (2015). Integration challenges of intelligent transportation systems with connected vehicle, cloud computing, and internet of things technologies. IEEE Wireless Communications, 22(6), 122-128.

Hamilton, A. J., Burry, K., Mok, H.-F., Barker, S. F., Grove, J. R., \& Williamson, V. G. (2014). Give peas a chance? Urban agriculture in developing countries. A review. Agronomy for Sustainable Development, 34(1), 45-73.

Johannes, E. M., Zulu, L. C., \& Kalipeni, E. (2015). Oil discovery in Turkana County, Kenya: a source of conflict or development? African Geographical Review, 34(2), 142-164.

Kerr, S., Colton, J., Johnson, K., \& Wright, G. (2015). Rights and ownership in sea country: implications of marine renewable energy for indigenous and local communities. Marine Policy, 52, 108-115.

King, M. (2013). Fisheries biology, assessment and management. John Wiley \& Sons.

Laxe, F. G., Seoane, M. J. F., \& Montes, C. P. (2012). Maritime degree, centrality and vulnerability: port hierarchies and emerging areas in containerized transport (2008-2010). Journal of Transport Geography, 24, 33-44.

Le Mière, C. (2014). Maritime diplomacy in the 21st century: Drivers and challenges. Routledge.

Lee, C.-J. (2013). China and Japan: new economic diplomacy. Hoover Press.

Manurung, H. (2014). Joko Widodo National Leaderships on Indonesia's World Maritime Policy. Available at SSRN 2510986.

Marshall, R. E., \& Farahbakhsh, K. (2013). Systems approaches to integrated solid waste management in developing countries. Waste Management, 33(4), 988-1003.

Michaels, J. D. (2014). Running Government like a Business-then and Now. HeinOnline.

Mukherjee, P. K., \& Brownrigg, M. (2013). Farthing on international shipping. Springer.

Nuechterlein, D. E. (2014). United States national interests in a changing world. University Press of Kentucky.

Rahman, A., Liu, X., \& Kong, F. (2013). A survey on geographic load balancing based data center power management in the smart grid environment. IEEE Communications Surveys \& Tutorials, 16(1), 214-233.

Ratcliffe, D. (2012). A nature conservation review: volume 1: the selection of biological sites of national importance to nature conservation in Britain (Vol. 1). Cambridge University Press.

Sheets-Johnstone, M. (2011). The primacy of movement (Vol. 2). John Benjamins Publishing Company Amsterdam.

Supriyanto, R. A. (2013). Indonesia and India: Toward a Convergent Mandala. India Review, 12(3), 207-224.

Thelen, K. (2012). Varieties of capitalism: Trajectories of liberalization and the new politics of social solidarity. Annual Review of Political Science, 15, 137-159.

Thuy, P. van. (2014). Beyond political skin: convergent paths to an independent national economy in Indonesia and Vietnam. Leiden University.

Venable, J., Pries-Heje, J., \& Baskerville, R. (2012). A comprehensive framework for evaluation in design science research. International Conference on Design Science Research in Information Systems, 423-438.

Wahlström, A., Larsson, O., Oltner, J., Wrådhe, H., \& Aurell, E. (2015). Steering towards the environmental objectives: The Swedish Environmental Protection Agency's in-depth evaluation of the environmental objectives 2015.

Wang, W., Liu, H., Li, Y., \& Su, J. (2014). Development and management of land reclamation in China. Ocean \& Coastal Management, 102, 415-425.

Zhang, Y., \& Buzan, B. (2012). The tributary system as international society in theory and practice. The Chinese Journal of International Politics, 5(1), 3-36.

Zhongping, F., \& Jing, H. (2014). China's Strategic Partnership Diplomacy. 